\title{
A narrative hermeneutical adventure: Seafarers and their complex relationship with their families
}

\begin{abstract}
Authors:
Chris J. Viljoen ${ }^{1}$

Julian C. Müller ${ }^{1}$

\section{Affiliations:}

${ }^{1}$ Department of Practical Theology, University of

Pretoria, South Africa

Note:

This article has been adapted from Ds Chris Viljoen's PhD dissertation, which was completed under the supervision of Prof. Julian Müller in the Department of Practical Theology, University of Pretoria, South Africa.

This article is published in the section Practical Theology of the Society for Practical Theology in South Africa.

\section{Correspondence to: Chris Viljoen \\ Email: \\ anchri@mweb.co.za \\ Postal address: \\ Postnet 129, Private Bag X504, Northway 4065, \\ South Africa \\ Dates: \\ Received: 01 Sept. 2011 Accepted: 19 Dec. 2011 Published: 02 May 2012 \\ How to cite this article: Viljoen, C.J. \& Müller, J.C., 2012, 'A narrative hermeneutical adventure: Seafarers and their complex relationship with their families', HTS Teologiese Studies/Theological Studies 68(2), \#Art. 1171, 12 pages. http://dx.doi.org/10.4102/ hts.v68i2.1171}

C 2012. The Authors. Licensee: AOSIS OpenJournals. This work is licensed under the Creative Commons Attribution License.
This research project is an attempt to develop a rich understanding about the relationship between seafarers and their families by means of a conversational construction between a number of co-researchers. In order to do this, the question that is explored is: How can there be a better understanding of the lives, the circumstances and the problems that seafarers are experiencing in the relationship with their families? The answer put forward in this research is that this can be accomplished through a narrative approach guided by the ABDCE formula which applies the metaphor of story writing to research. The research was motivated by pastoral and missionary concerns. The epistemologies that informed this research were social constructionism, the narrative approach and postfoundationalism with its emphasis on the interdisciplinary approach. In this article the main character for this research was a seafarer called John ${ }^{1}$ from Nigeria who was brought into conversation with a number of other coresearchers. The understanding that was developed found that the career choice of seafarers creates problems in their relationship with their family because they become in a sense strangers and outsiders to their loved ones. On the other hand seafarers are empowered, many times through their faith, to handle the challenges of their career, in addition to which this profession offers opportunities that would otherwise not have been possible. The relationship between a seafarer and his or her family was described as a complex one and thin, superficial and stereotypical conclusions were hopefully in the process deconstructed.

\section{Introduction}

John is a seafarer from Nigeria. I met him through my ministry to seafarers in the port of Durban. Getting to know John over a period of more than a year confirmed to me that seafarers are simply people who are husbands, sons, friends and fathers (or wives, daughters, mothers) like all other people. The lives of seafarers are at times very isolated because of being far away from their families for long periods of time and also because they are often viewed in a stereotypical way.

Tronche (2008:382) describes how fishers are sometimes referred to in his experience as: '... drunkards, cannabis smokers, foulmouthed, promiscuous guys whom you simply cannot trust ...' This is a 'thin' narrative and it is unfortunately also at times applied to seafarers in general. My research was an attempt to develop a thick or rich narrative concerning seafarers and the world in which they are living. With 'thick' is meant that by means of the description and the understanding that was developed through this research, an attempt was made to avoid being one-sided, superficial and without the complex meanings that are attached to behaviour. Morgan $(2000: 12,13)$ points out how 'thin' descriptions lead to a simplistic understanding of life and of people's identities and that when this happens this has serious negative consequences. The problem with thin descriptions is that they ignore the complex nature of our existence (Morgan 2000:12). Morgan (2000:15) says: "The opposite of a "thin conclusion" is understood by narrative therapists to be a "rich description" of lives and relationships.' The hope is that in this article a rich or thick description will be developed.

The whole concept of 'thick description' is actually a very loaded term which originated with the philosopher Gilbert Ryle (Geertz 1973). According to Ponterotto (2006:539), for Ryle 'thick descriptions' were about 'understanding and absorbing the context of the situation or behaviour.' The concept of 'thick description' became widespread in qualitative research through the work of Clifford Geertz who applied it to anthropology (Ponterotto 2006:539). For Geertz (1973) a 'thick description' is about taking seriously the idea of Max Weber who said that 'man is an animal suspended in webs of significance he himself has spun'(Geertz 1973:2). A 'thin description' would be to ignore these webs and to try and describe behaviour as if it is not embedded in this. A 'thick description' can also be explained in the following way:

1.This research was approved by the ethical committee of the University of Pretoria. Permission to publish the stories was obtained from the seafarers (no real names were used in this article). 
A thick description ... does more than record what a person is doing. It goes beyond mere fact and surface appearances. It presents detail, context, emotion, and the webs of social relationships that join persons to one another. Thick description evokes emotionality and self-feelings. It inserts history into experience. It establishes the significance of an experience, or the sequence of events, for the person or persons in question. In thick description, the voices, feelings, actions, and meanings of interacting individuals are heard. (Denizin in Ponterotto 2006:540)

In order to reach this deep and thick description and understanding of seafarers and their relationship with their families I have embarked on what could be called a hermeneutical adventure. The research process is seen as a hermeneutical adventure because it is about understanding and therefore it is about a hermeneutical process that is taking place. The idea of seeing research as a hermeneutical adventure is borrowed from Müller (1996:12) who describes therapy in this way. In this hermeneutical adventure the purpose was not to discover something objective, but to coconstruct an understanding, together with my co-researchers, which arises from a particular local context.

The research could broadly be described as qualitative research, but it was a specific kind of qualitative research namely narrative research. In order to guide the research, the ABDCE formula for research was followed. This research project asked: 'How can there be a better understanding of the lives, the circumstances and the problems that seafarers are experiencing in relation to their families?' The answer, which is explored in this research, is that this can be accomplished through the narrative approach guided by the ABDCE formula.

The idea of using the ABDCE formula for research comes from an article by Müller (2001): 'Therapy as fiction writing'. In this article the formula is applied to narrative therapy, but in a later article Müller, Van Deventer and Human also applied it to narrative research (Müller, Van Deventer \& Human 2001; Müller 2003). Müller's (2001:65) ideas are developed from Anne Lamott's book Bird by Bird, in which she used Alice Adams' ABDCE formula on how to develop a story. The metaphor used implies that in the same way a story develops while a writer is busy writing it, in a similar way the story of someone in therapy is developing while the process of therapy is taking place. This idea is then extended to the development of a research narrative.

The ABDCE formula for the development of the story refers to Action, Background, Development, Climax and Ending (Müller 2001:65). The advantage of using this formula is that the process is seen in a holistic way because, although you might come across many stories through your research, in a certain sense the research project is only one story that is being developed (cf. Müller 2001:65). The 'A', the action can be seen as the 'now' of the story and the challenge for the counsellor or researcher is to stay in the now (Müller 2001:66). The idea is to open space for the action and to keep in mind that the action is more than the problem. Müller
(2003:10) says that to see the action as more than the problem, is because of the researcher's deconstructive stance. This means that the researcher is not only a reporter of stories that already exists, but that the researcher is actively involved in the development of the story which is what the ABDCE formula guides the researcher towards. If the researcher did not see the action as more than the problem, the end result would be a document reporting on problems.

In order for the narrative to be rich and to develop into more than a superficial description of problems, it is also important to include enough background ' $B$ '. Müller (2001:67) states that as far as the background is concerned, it is no longer just about the now, but also about the past and for this reason the broader context in which the action is taking place becomes relevant. Here the researcher is interested in detail; this detail includes personal information and it is appropriate to invite someone to share this, as this helps the story to develop to its fullness (Müller 2001:66, 67). The background is needed in order for the story to develop.

Background and action should not be seen as two things that are separated from each other. Müller (2003:13) states that there should be a reciprocal dialogue between the two and that the steps of socially constructed narrative-based research should not be seen as moving in a linear way, but rather as moving in a spiral. When the researcher and the co-researchers participate in the action, and the background is plotted into the new research story, development will start to take place.

Müller (2001:67) states that the attitude of the counsellor (or researcher) should be one of patience and curiosity. A researcher should have the attitude of not knowing what the solutions to the research problem and questions are or should be, and should see the research as an evolutionary process in which the co-researchers are active participants (Müller 2003:13), contrary to some research where people are used as passive objects. Narrative research is not just story writing but also story development (Müller 2003:13). The hope is that a story will develop that is better and that can lead to emancipation (Müller 2003:14).

The climax ' $\mathrm{C}$ ' is about 'things coming together' (Lamott in Müller 2001:68). This can take a long time and the writer or therapist or researcher needs to be willing to wait (Müller 2001:68). Here it is necessary to, in a certain sense, get out of the way. Müller (2003:14) says that you should be patient as far as the climax of the research story is concerned because to understand too quickly is not to understand at all. When you are not patient, true research has not taken place and your research becomes just propaganda for the researcher's own agenda (Müller 2003:14). For Müller (2003:15) the remedy for understanding too quickly is to let the research unfold through the ABD phases in an authentic way. As researcher you should not be overly ambitious as to what you can achieve with your research, therefore when Müller (2003:15) talks about the climax he refers to it as: 'some sort of a climax.' 
However, Lamott (in Müller et al. 2001:86) states that after the climax things are 'different in some real way.'

The ending ' $E$ ' is about the end of writing down the story, the end of the client's coming to see the therapist or the end of a research project. At this stage you learn that the climax was not really everything that came together in a neat and systematic way. Lamott (in Müller 2001:69) says that this means that at this stage you might find yourself unable to make interesting conclusions or to reduce some negative emotions and that the challenge for you is to accept things. To make artificial changes in order to make everything sound sensible means that you are not true to the whole process. Müller (2001:70) says that although during the therapy process a lot of stories are told, 'therapy creates its own story.' In the same way it is the belief that this research will create its own story (cf. Müller 2003:15). The hope is that this story will create new possibilities and open space for new research stories to develop (Müller 2003:15). Therefore the end is not a conclusion (Müller 2003:15). Things are not neatly wrapped up and packed away. The end will not always be happy, but in some sense the end will be better than the beginning (Müller 2003:15), assuming that the researcher and co-researchers were true to the process. The end might be disappointing, but the perspective will be new and in this sense it is better than the beginning (Müller 2003:15).

At the end of this section an important question that could be asked is: why this approach is chosen instead of another? In this article the claim is not whether this is the only way to do research, but the argument is whether this is a good approach which will give results that are worthwhile. This research approach, as was pointed out earlier, leads the researcher to develop one story (cf. Müller 2001:65). In other words it gives a sense of coherence to the whole project even though it might consist of many aspects and themes as well as a variety of research characters. Using the ABDCE formula helps the researchers to weave together a lot of story lines into one plot. In addition this approach is not a rigid recipe, but a flexible guideline.

For instance, even though there are other researchers who have used this method before (which affirms the argument that it is a good research approach), it was not difficult in this specific research project to incorporate the notions of the postfoundationalist approach. Although not incorporated in the original design, it was easy to simply view the scholar - Surita Stipp from the systemic family therapy - as a coresearcher who could contribute to the thickening of the plot.

Further, the ABDCE formula assists the researcher to develop a rich understanding with thick descriptions. It leads one to observe the action ('A') carefully, to make sure that there is enough background; it helps the researcher to stay with the research character or characters in order for the research story to develop to where an alternative perspective can emerge. It guides the researcher to not understand too quickly and therefore it helps to avoid not really understanding
(Müller 2003:14). This approach, if used correctly, guides the researcher to be patient and to develop interpretations which are truly new and hopefully empowering.

Lastly, this approach is developed in the context of taking your research characters very seriously and to view them as co-researchers and therefore with respect. They are not seen as 'objects of information' but rather as 'subjects of communication', as Dreyer (1998:23) advocated (although not referring to the ABDCE formula).

In the next section the ABDCE formula will be implemented in the development of a thick description.

\section{Action: The problems that were researched and the research problem}

The research problem can be described as being the need for a better and deeper understanding of seafarers and the world in which they are living in order to deconstruct and avoid thin conclusions. The objective is to move beyond a simplistic and superficial understanding of seafarers and their circumstances in order to co-construct new empowering interpretations that might point beyond the local. The assumption is that a better understanding will lead to a better ministry because if a persons' concept of reality changes then a person's actions can also change (cf. Demasure \& Müller 2006:412).

The problems that will form part of the research will be the problems that are part of the narratives that the seafarers and the other co-researchers (Stipp 2011 and the chaplains) described. It must be emphasised that these narratives should grow out of a particular context. In this article the focus will be on the problems that seafaring creates for the family, but true to the nature of the narrative approach, a special interest will be placed on alternative stories that might point towards positive empowering aspects that seafaring has for seafarers and their families.

\section{Background Seafarers' Mission}

I am working in the port of Durban as a chaplain and missionary which is the context in which this research originated. The organisation I work for is called the Christian Seaman's Organisation; it is a South African organisation that is funded primarily by individuals, from congregations of the Nederduitsch Hervormde Kerk van Afrika and the Dutch Reformed Church. This organisation is part of a larger international ministry that is collectively referred to as the seafarers' mission. As part of my involvement in this ministry I met John and in conversation with each other we developed an understanding of the way in which seafaring has a serious impact on his relationship with his family.

In the 1800s when someone heard of the initiative to minister the gospel to seafarers he exclaimed: 'You might as well 
preach to the mainmast!' (Kverndal 2008:xxv). It was widely believed in those days that a sailor had no soul (Kverndal 2008:xxv). They are normal human beings, though and therefore from a missionary and pastoral perspective, in need of Jesus Christ like everyone else. Based on this perspective, it can be said that God uses the seafarers' mission to witness to and with seafarers. This emphasis, that it is God's initiative, will later be more fully explained under theological issues.

According to Mooney (2005:19) ship visits and seafarers' centres have been an important strategy of mission work in the past, but he implies that it is no longer effective as the only approach. Seafarers' centres, also called clubs or the Seafarers' Mission, are places where seafarers can relax, call their families, do a bit of shopping and have access to the Internet. Managing these clubs is often a combined effort between different organisations as is the case in Durban harbour. In the past, it has been a very effective way of ministering.

The reason why this approach to the ministry is in a crisis is partly because the time of ships in port is getting shorter, as their owners want to transport as much cargo as quickly as possible from one port to the next (Mooney 2005:57). According to Trotter (2008:9) one of the biggest changes in the seafaring world came about with containerization. The impact of this was at least twofold: ships could load and unload much quicker and the size of the crew was reduced (Trotter 2008:10). This started to happen already in the midsixties (Trotter 2008:9). The International Ship \& Port Facility Security (ISPS) code as well as the Flag of Convenience (FOC) system also had a great impact on the lives of seafarers. The ISPS code got rid of all the superfluous persons on the docks under the initiative of the United States of America (USA) after 9/11 (Trotter 2008:31). According to Trotter (2008:31) this code isolated the harbour areas from the rest of the cities and made the seafarers even more socially isolated than they were before. Largely due to the FOC system the composition of the crews that sailed the ships started to change rapidly (Kverndal 2008:140). This system means that ship's owners can chose to register their ships under a country's flag which offers them tax benefits or lower standards for safety, justice and welfare (Kverndal 2008:XXIV). Owners can do this irrespective of their own nationality. Owners hired mostly Asian crews because they could be paid much less and they were normally not so well connected with unions as their Western counterparts (Kverndal 2008:140). This also meant more social isolation as this led to a situation where persons of different nationalities, who many times could not understand each other well, had to sail together.

\section{Epistemological position}

I have already explained that this research can be seen as narrative research. Narrative research could mean more than one thing. It could mean that you are simply interested in stories. In this research, however, narrative research refers to an approach which grew out of the ideas of social constructionism. Social constructionism holds that language constructs reality and that in dialogue with people you can co-generate a new reality with new ideas and meanings, because meaning is created in relation with others (Demasure \& Müller 2006:416). Thayser (2001:65) refers to Hoffman who pointed out that the self is no longer seen as being 'an internal construction' but rather as something being socially constructed and therefore a 'social artefact'. Gergen (1993:234) states: '... "to be" a self is already "to be with"...' Whilst doing research it is important to emphasise that social constructionism holds that knowledge is not simply discovered as if it is an objective thing that exists. Thayser (2001:67) points out that Gergen asserted that knowledge arises through social cooperation. In this research the point of view is, that through the social involvement of different people who have a shared interest in a certain topic or question, new knowledge can be developed. New knowledge is possible because as Gergen (1985) states:

The terms in which the world is understood are social artefacts, products of historically situated interchange among people. From the constructionist position the process of understanding is not automatically driven by the forces of nature, but is the result of an active, cooperative enterprise of persons in relationships. (p. 266)

Gergen (2001:808) points out that in modernism 'one is taught to take marching orders from reality'. In social constructionism there is a realisation that the 'marching orders' are socially constructed and when there are harmful ones it is possible to socially deconstruct them. When this is done one can say that the research has been successful.

This research was further influenced by the ideas of Van Huyssteen's postfoundationalism, especially as far as his emphasis on the interdisciplinary approach is concerned. According to Van Huyssteen (1997:2) the question is, whether Christian theology can join the postmodern conversation and still maintain its identity. In other words, the question is whether there is a possibility that theology can interact and communicate with science without ceasing to be theology in the true sense of the word.

For Van Huyssteen (1997:4) the aim with postfoundationalism is 'to identify the shared resources of human rationality.' That can be done through a postfoundationalist position in dialogue with other disciplines. In postfoundationalist Christian theology you have to become aware of hidden beliefs and assumptions that you take for granted in order to be in this cross-disciplinary conversation (Van Huyssteen 1997:4). Stone (2000:417) says that for Van Huyssteen it is about constructing a notion of rationality that can take theology out of isolation into a sphere where theology and science are both equal partners. In this research the approach was to enter into an interdisciplinary conversation with systemic family therapy.

The type of rationality for which Van Huyssteen argues, can be called 'transversal rationality', referring to the point where one line crosses other lines as a metaphor to describe how different 'discourses, modes of thought and action' intersect with each other (Stone 2000:418). Müller (2009:206) 
also states that the idea for theology, in this approach, is to act as an 'equal partner' in the interdisciplinary conversation in the postmodern context of today. In the interdisciplinary conversation the hope is that we are no longer 'hopelessly culture and context bound' (Van Huyssteen in Müller 2009:206).

Different disciplines do not have to contradict each other on the one hand, or merge with each other on the other hand, when interacting (Van Huyssteen 2000:429). Van Huyssteen (2000:431) asserts that it has been discovered in this type of conversations, that one discipline or reasoning strategy cannot contain human rationality in its fullness. The realisation of the limitedness of your own discipline's rationality makes it an imperative to seek out transversal connections with other disciplines.

It needs to be stated clearly though, that when these connections are searched out and looked for there is no need to become an expert in another discipline because although this might be possible, practically it would be a great challenge. What is required is a mutual concern, and of course, enough knowledge to be able to have a meaningful conversation with another discipline. I do not need to become an expert on systemic family therapy in order to make use of the rich resources that this discipline is able to offer. What is required is a conversation where equal partners are able to discuss mutual concerns. What is hoped for is to develop an understanding based on a conversational construction between different disciplines (cf. Wildman 2008:476) where they act as equal partners.

\section{Theological considerations}

Mostly when the question of what truth is, is talked about in the narrative approach, the answer would be that truth is what is socially constructed by a certain group of people and the assumption is that it is only people who participate in the social construction. In postfoundationalism, like in social constructionism, the emphasis is on the fact that we are relational beings (Demasure \& Müller 2006:418). I agree with the emphasis that meaning and interpretation are socially constructed, but my theological position is to add that Jesus Christ is part of our social reality. The God in whom the church believes is Immanuel (Mt 1:23) and He is that because He is love (1 Jn 4:16). Based on this belief the church cannot do any different than to reach out to seafarers who are strangers and who are often in need of help, and of course, who need to hear the good news about a loving God. It can be said that this is what the church should do because God is who God is.

Mission is not an invention of Constantine or colonial imperialists. Mission is part of what makes church truly church. With the concept of Missio Dei, David Bosch (in Niemandt 2007:147) emphasised that God is not only busy with and involved in mission, but that mission is part of the essence of who God is. The seafarers' mission can be said to be a movement which is participating in the Missio Dei.
The notion of Missio Dei is based on the way in which the Bible describes and views mission. In Luke-Acts for instance, we get the notion that mission work and the church's participation in it is actually God's own work, God's initiative and God reaching out to people of all backgrounds and religions. According to LaVerdiere and Thompson (in Bosch 1991:88) in Luke-Acts Jesus' mission is incomplete and the church is called to complete it. We are called to continue what Jesus did on earth. This is done through the work of the Holy Spirit who did not only initiate mission but also kept on guiding it, according to Luke-Acts (Bosch 1991:114). In Luke-Acts mission is not just about the spiritual, though, it is also very much about economic justice (Bosch 1991:117). It is not only about the relationship with God, but also about relationships between people. Through Christ, relationships have been made new. In Paul's letters we read that the church is the forerunner of the new creation and it is that especially by showing that normal human distinctions like race and culture no longer define who we are, and therefore the normal borders between humans are no longer applicable (Bosch 1991:172). The seafarers' mission is an expression of this through the continuous acts of reaching out across the borders and distinctions. The church does not do this to benefit itself, though. For Paul the church is not the aim of mission, but the aim is rather to participate in God's plan of salvation for the whole world (Bosch 1991:178).

These are some missiological concerns, but they are also closely related to practical theology which was actually the department in which this research originated. Gerkin (in Van der Westhuizen 2010) states that practical theology is not only concerned about the ministry of the church to herself, but it also has to do with the church's involvement with the world. This brings these two theological disciplines together and expresses something of the overlap between them.

Practical theology gets its life from its particularity (Müller 2005:79). By describing a particular context and situation not only in my own words, but in partnership with the seafarers, a conversational construction can emerge which can give the reader a 'feel' of the people and their lives with whom I am doing research (cf. Neuman 1997:328). This research narrative is a contextual, embedded social construction. It is not about practical theology referring to seafarers' lives and circumstances, but it is a practical theology growing out of specific seafarers' lives and their circumstances (cf. Müller 2004:296).

Christian practical theology has the challenge of bringing two particular, concrete contexts into communication with each other. According to Müller (2005:73) practical theology is happening where there is a reflection on practice from the perspective of the experience of the presence of God. This experience of God's presence has to do with a particular context in which a certain person experiences God, but in Christian theology it also has to do with the specific experience of God in Jesus Christ. Gräb (in Müller 2011) states: 
Practical theology needs to explore how the symbolic strength of Christianity for making sense of life and for successfully coping with life can take shape in the church under today's complex social-cultural conditions. (p. 4)

This definition points towards focussing on particularity. It refers to paying attention to a concrete situation's specific social-cultural characteristics. It also talks about the 'symbolic strength of Christianity.' However, this symbolic strength grew out of a particular context of which the core is the concrete historical event that the Word became flesh in Jesus Christ and that He still dwells amongst us in our particular contexts. In this research narrative the challenge is to stay grounded in these two particular contexts and to bring them into conversation with each other.

\section{Methodology and methods}

In this research there are three research movements guided by the ABDCE formula. These movements refer to the different groups of researchers whom I invited to participate in the co-construction of an understanding. The first movement will focus on seafarers (especially focusing on one seafarer) in their particular concrete situation, the second movement will be to try and find a transversal connection with a nontheological discipline and lastly I will share some of the things that other seafarers and chaplains, who are experts on the lives and circumstances in which seafarers are living in, shared with me.

The idea to call the involvement of the three different groups 'movements' was taken from Müller (2009). He referred to movements as he approached different groups of coresearchers to participate in his study at different stages. My first research movement was to become part of the action and to broaden the background through interacting with seafarers in their situation and context. I started to visit ships and to interact with seafarers at the seafarers' centre. Eventually I also conducted interviews with some seafarers. This article will primarily focus on an interview with John at the seafarers' centre where we talked about some of the struggles in his relationship with his family. Based on this interview I entered into a conversation with systemic family therapy informed by the notions of Van Huyssteen. Here I followed Müller (2009:227) who developed three questions as a way of engaging another discipline in an interdisciplinary conversation. These questions are the following:

1. When reading the story of John, what do you think will his or her concerns be? (Other seafarers' experiences were also shared, but in this article the focus is on John.)

2. How would you formulate your discipline's unique perspective on these concerns and why is it important that this perspective be heard at the interdisciplinary table?

3. Why do you think your perspective will be understood and appreciated by researchers from other disciplines?

\section{Pastor John from Nigeria Introduction}

John was an electrical officer on a very old salvage tug in need of urgent and expensive repairs. He was also a charismatic pastor who ministered to many people here in South Africa for the duration of his stay. Some people even, against all port regulations, managed to visit his ship so that he could minister and pray for them. The Nigerian owner who bought the ship, sent John and the other crew to Durban in order to sail it to Nigeria where the plan was for it to provide supplies to the oilrigs. John was promised that it would not be more than three months before he would be home. In the end he stayed for more than a year in Durban, many times without much money to call home, as the payment of his salary did not happen on a monthly basis as it was supposed to.

I became part of the action by means of visits to John's ship every now and again. Eventually I got to know the crew well and I started to conduct a weekly Bible study on their ship where John was the most consistent participant, but at times even two of the other crewmembers, who were of the Islamic faith, joined us. This was a unique situation because in the seafarers' mission your interaction with seafarers is normally limited to a very short period of time. Many times you meet seafarers only for a few minutes and never see them again. This provided a unique opportunity for me as a researcher.

\section{Getting to know John and his family}

This research is about giving seafarers a voice and in this section it will be important for me to let John tell his story in his own words as far as seafaring and his family are concerned (cf. Müller 2003:8). John was very open-hearted about his family and his marriage and talked about it in fluent English, albeit with a heavy Nigerian accent:

'And talking about family. I have started going to sea when I
married. I married some 19 years ago and the very first thing
I experienced was when I got married, immediately [after] I
finished my marriage, I was taken away from my country to
Liberia where I stayed for six months before I saw my wife again.
And it was the very first time I knew: "Okay, working at sea is
not always a bed of roses." Cause, it was, when I got back home
another man was almost taking over my wife cause [laughs],
because in fact there was even a rumour or two [which] had
[it] that I was not to coming back; that I have married another
woman. But God helped me: when I came back I met her and it
has been a wonderful marriage with her for this long. So that is
what I can tell you.' (John)

John explains how difficult it was for him from the start of his career and that seafaring complicated his marriage relationship. I asked him about his children:

'Yah, my first child is 18, my second child is 16 and then my last children who are twins are 13. The impact of my profession on ... on my children just like it is with most other seafarers, is that they don't experience the true fatherhood, you know. It's like most, you discover that it is common among seafarers that their children will take almost $75 \%$ of their upbringing from their mother and then that affects ... it affects their outlook. So as I am now I put in a lot of energy to be truly $[a]$ friend to my children. What I do, when I go home I put in so much energy otherwise the job estranges me from my children, makes me a stranger to them. And no matter how I try, that is just the way the job is. So, but thank God, my children, because of our Christian orientation, they tend to understand. And I keep telling them: “Well, don't 
rush to take this profession because I am not so happy that I [am] always missing you guys. That is the profession that is making me to miss you guys." So it is ... that is how it is with children.' (John)

There are a few important issues that John is talking about here, relevant to understand what many seafarers (in my experience) are going through concerning their relationship with their families. A lot of what John says strikes me as being very familiar as I hear similar things almost on a daily basis in conversation with other seafarers. John talks about his wife and then his children. As far as his wife is concerned he says: '... working at sea is not always a bed of roses.' Seafaring disrupted his relationship with his wife from the beginning of their marriage and almost defined it. Emotionally, it had put his wife in a bad place. On the one hand she heard rumours that her husband had another wife, and on the other hand it seemed that it made her vulnerable to be open to the attention of another man. As will be emphasised in conversation with systemic family therapy, this was at a very fragile stage in the marriage. Seafaring was from the beginning a defining factor in their relationship and was something that almost took control of John and his family life. It is as if it took John by surprise and therefore he warns his children against following in his footsteps because as with this marriage, seafaring also determined, or at least influenced greatly, their whole relationship. He says: '... they don't experience the true fatherhood.' And again the idea appears that seafaring is a thing or a power that took over the initiative in their relationships when John says: 'And no matter how I try, that is just the way the job is.' The Job is acting like a power, or a person which is contaminating and influencing all the relationships in a powerful and negative way. By calling seafaring the The Job, I am using a technique well known in narrative therapy. With this the problem is usually externalised and this helps one to explore the relationship of the person with the problem. As Epston and White (1990:38) pointed out: 'In this process, the problem becomes a separate entity and thus external to the person or relationship that was ascribed as the problem.'

The Job cannot be described as a problem as such, but this technique is helpful to describe and explore the relationship between seafarers and their families. Although The Job is causing a lot of problems there is also an alternative perspective on this relationship. For John this alternative perspective is based on his experience of the presence of God in his life. Both with his wife and his children it seems that for John there is a sense of being able, through the help of God, to overcome the overpowering force that The Job exerts on their family relationships. When he went home after the drama with his wife he says: 'But God helped me: when I came back I met her and it has been a wonderful marriage with her for this long.' With his children God's presence is helping them to have patience and empathy with their father's chosen career: 'So, but thank God, my children, because of our Christian orientation, they tend to understand.'

In John's experience and understanding The Job influences the relationships with his wife and children negatively but his experience of the presence of God is that this is what helps them to overcome a lot of the challenges. Not that, after this first challenge, everything was smooth sailing between him and his wife. The plot thickened:

'And now I am talking about, because you are always away from your families, both male and female seafarers they are not very faithful to their spouses, you know. You need to struggle to be able to keep the ... your faith as a Christian, while away from your family. So these two major things are very challenging. I, myself in particular, and most seafarers generally. [ $\mathrm{I} \mathrm{am}$ ] talking about how difficult, or how easy it is for a Christian to be on board, that's just the way it is.' (John)

'And you have seen other people, Christian people that struggle with being faithful with their, their husband or wife and, and that's happening a lot. It's, it's difficult for you to have Christian values and to live them [out] on a ship because the people around you is, is not doing it, they are not living a Christian life. So there is this group pressure so ... you also said about the rituals that they have, they expect you to participate. And also with, with your whole group is, is, is not faithful there is some expectation and there's some pressure on you to conform to the group so, I think that makes it very difficult.' (Chris)

'Yah, you're right. You're right, actually what you have asked, said, now reminded me of when I failed from my Christian faith. One occasion I was away from my family, I was married with my first child. And because of the kind of peer pressure I faced on board with regards to going out with strange woman, I failed and I hurt and I failed. And I, I, I, did that for a couple of times and when I realized myself I only wake up [in] tears. I ... it took me a very long time to get myself back to... So, that is what it is, if you are inside the ship you will always be faced with the pressure, to follow the crowd, to you follow, you know, the majority, because that is what majority see, and they cannot stay without doing some kind of sinful things. Especially going after ... going into perverse outside their marriages.' (John)

Previously, John had said that after the first incident when his wife had thought he got married to another woman, it 'has been a wonderful marriage.' Here he tells us that although they might in general have a good relationship it has not been without some serious challenges because of The $J o b$, because in spite of his commitment to his faith in Christ he was unfaithful to his wife. I knew John very well for more than fifteen months and experienced him as a person of integrity who practiced what he preached, but even for him, on one occasion, the temptation became too much. For me this shows that it is very difficult for seafarers to be faithful to their spouses because they have many opportunities to be unfaithful, they are in a social environment on the ships where this is not considered a big moral failure. Recently a married Filipino seafarer told me that, although he was not sure how it happened, he wanted to get married to a Brazilian girl and he gave her a lot of money for the marriage ceremony. After their ship sailed he came to his senses and in time he told his wife about this. She responded in saying that it was okay if he was unfaithful to her, as long as there were 'no strings attached' to these other ladies. When he told me about this he was amazed and puzzled about the way he acted. 
These type of happenings can have an impact on the relationship between spouses for many years after the incident. The influence of this was probably visible in the manner in which his wife reacted to the situation John found himself in here in Durban. He said:

'... you see like my wife phoned me one time and said if I know that I have married here I should let her know [laughing]. So I was just, there was a time I had to plead with your wife Reverend Anneke to talk with my wife, and, so that she could be encouraged. In fact there was a time she went to the office, our office in Nigeria to enquire: "Is it true that you are the ones holding my husband or he has married there and he is living with another person there?" So, she was ... in the office, they say: "Yah woman that is what is happening." Yah, my children are more understanding, maybe because they are children. It has not been very easy with my wife.' (John)

Similar to the very first sea voyage John says that it happened again: his wife thought he got married to another person. The whole situation is difficult for a wife at home, much more so if the husband, like John, was unfaithful before.

The relationship with his children seems to be a bit better. He said that it might be because of his children's Christian orientation and also just because they are children. Even so, it is not easy with children. I asked him about coming home:

'Yes, yes, I want to tell you that I was just, in a deep thought one time, one time and I began to see: "Oh, so if I had died, so my wife, my family will still get along." So that thought was just coming to mind. I said: "Okay, that's a good one too, that if I had died for this length of time they would be living." So, what I want to say is that normally when I get back home, I can, I can tell you that it would take some time before I will be part of them again. I'm going to be a total stranger. 'Cause what has been happening, talking about, I talk with my wife every day. ... because of the cost of airtime, we don't talk, we don't talk with the level of affection that we should talk. So we just try to talk: "Is there anything wrong, what is happening?" Like that. So when I come back home now, I am going to begin to see how I can refit myself into, to their routine of life, you know, the way they see life and the way things are with them. So, yah, it is not easy, but I am going to try. It is part of what I am doing ..., will make our reconciliation very quicker ... faster when I get home. That's, there's no doubt that I'm going to enter my house as a stranger. It will only take time for me to begin to work together again.' (John)

John realised that because of The Job he became in a sense a nonessential member of his own family (except of course for providing money). He views this in a positive light because he knows that if he would pass away they would be fine. This, however also means that because they are doing well without him it is not an uncomplicated matter to simply reintroduce himself into the family. On the telephone it is not always easy to have a proper conversation with the 'right level of affection' and so in the end a situation of being a stranger in a certain sense seems to be unavoidable. John's remedy to this is to make a conscious effort to readjust to the family.

Based on conversations I had with other seafarers confirming that adjusting to the family was not a very simple matter, I was interested to find out if it is true that, when seafarers are with their families they cannot wait to get back to sea:

'Yes, yes, especially when that happens I was younger. You see I am forty-six now. When I was younger the sea life used to excite me. And I want to get away from, you know, the hustle and bustle of the city. I want to go to the water environment, so [it] used to be like that for me. But now, I am always thinking of home now.' (John)

This was after John had been away from his family for fifteen months and therefore his mind was constantly with his family. Previously the 'sea life used to excite' him, but at the age of forty-six he is no longer enticed by the sea. John did not say it in as many words, but that is the problem with The Job. If it was only bad and negative, like seafarers from all cultural backgrounds always say: 'No problem'. Now, however The Job has a lot that repulses and that attracts at the same time. It is a blessing and it is a curse. It is 'not a bed of roses' for you and your family but it does provide possibilities that would otherwise not have been there. It is in many cases even an abusive relationship.

\section{Bringing John into conversation with other seafarers, chaplains and systemic family therapy about The Job}

This section can be seen as the ' $C$ ', the climax in the ABDCE formula. The hope is that in this section something of an 'aha-experience' will evolve through collaboration between the different co-researchers. The climax is where and when things are coming together (Müller 2001:68). In this part of the article I will bring together the different voices of the coresearchers concerning the topic of seafarers' relationship with their families.

Seafarers are more away from their homes than being there. The result of this, as was pointed out, is that their children and wives sometimes become strangers to them and that their role in the family is reduced to being the person who makes sure they have money (Trotter 2008:39). So on many occasions a very high emotional and relational price is paid as far as a seafarer's family is concerned, but of course they get a lot in return as well. Seafarers can provide opportunities for their children that would never have been possible without this career, and many times it is not only their own children who benefit, but also many other family members (Otto 2002:35).

There are advantages and disadvantages for seafarers and their families. My understanding of seafarers and the relationship with their families based on the stories that my co-researchers told, and also other stories I have encountered, is that there are constantly forces working in on them. Forces that pull them back to sea and forces that push them away from their families. On the other hand there are also forces that bring them back home and forces that push them away from the life at sea. Their lives seem to be doomed to be lived between these forces and many of them only hope that their children will have a better life because of their sacrifices (the 
word 'sacrifice' is a word seafarers themselves often use when talking about their relationship with their families).

Another co-researcher, who had been sailing for many years, said that families 'must accept the disadvantages of the advantage they all enjoy.' These disadvantages sometimes mean that their families have to suffer a lot. As one seafarer's wife (in Otto 2002:13, 14) described how difficult it was when her husband came home for vacation: 'When the honeymoon period is over how difficult everything becomes! Everybody comes back down to earth.' Much of what the co-researchers said tends to agree with this statement.

John said: '... immediately I finished my marriage I was taken away...' With this he meant that just after his wedding ceremony he had to leave his wife to go on contract to sea for six months. This is where John's story with seafaring and family started off and unfortunately much heartache was still to follow.

As mentioned earlier in this article, I entered into an interdisciplinary conversation based on the postfoundationalist ideas of Van Huyssteen. I do not share all the things that were said in this conversation, but here I will only highlight certain insights. I entered into a dialogue with Surita Stipp who completed her Master's degree in systemic family therapy in Australia. For this reason I viewed her as a person who had access to rich recourses of human rationality which is not available to me but in which I can share according to the postfoundationalist ideas of Van Huyssteen, as already explained. In the postfoundationalist view there are many methods with which it is possible to have an interdisciplinary discussion; in this article my method was to share some sections of interviews with Stipp and to ask her to respond to them. In this way, she was able to apply her discipline's insights to the things that seafarers had to say about their relationship with their families guided by Müller's (2009:227) three questions.

From a systemic family therapy point of view Stipp pointed out how important certain stages for a family are and that when the seafarer misses the transitions from one stage to the other it can have a very negative impact on the family. She (Stipp 2011) says: 'During these periods they need to readjust and organise the family structure to fit $[i n]$ with new demands on the family system.' Probably this incident with John and his wife was partly caused because the stage after just getting married is an important transition phase. Stipp (2011) points out that: 'There was no time to adjust to this important life stage and the couple was left to continue their marriage separate from the start.' One of the chaplains who participated in the study intuitively agreed with this saying:

'I think a sailor should not go to sea for at least a year after getting married! I believe this used to be the case in Bible times for soldiers! He needs time to get to know his wife.'

The practical reality for seafarers unfortunately, is that they normally miss important transitions from one phase to the next; which can especially influence their relationships with their children. Stipp (2011) says:
A breakdown in attachment is one factor but also a loss of understanding about the stage of development the child is in, as well as the emotional needs of each individual in this process.

Stipp (2011) further pointed out another aspect that systemic family therapy sees as being important:

There is a hypothesis that a lot of seafarers choose this lifestyle in the first instance because they can't cope with the intimacy and demands of a life in an intact family where they are with their families constantly. They triangulate with their work as a seafarer to reduce the anxiety they feel in intimate relationships.

This might be an unconscious motive of some seafarers and might explain why some do not adapt easily when they are back at their homes. For John his career might have started like that, but things were different at the time of the interview: 'But now, I am always thinking of home now.' Being away from home for so long he was missing the closeness of 'intimate relationships': '... because of the cost of airtime, we don't talk, we don't talk with the level of affection that we should talk.'

Ivan, a captain from Bulgaria, had this to say about seafaring and family: 'No, it is not easy.' One of the chaplains also commented:

'This is maybe the main theme of all the seafarers I speak to. The loss of not being at home, not seeing how your children grow up, not having a good relationship with their partner because they are away from home. Stories of being at home, and then still fighting constantly are regular.'

Ivan continued:

'... there would be very few seamen, you know, not $[a]$ specific level, of any level, from the crew list, very few would be found, you know, to not be divorced.'

He elaborates on how a marriage can be difficult for both the husband, who is usually the seafarer, and the wife who is normally staying at home:

'It's a difficult thing, it is a difficult thing for women and it's a difficult [thing] for the man. For a woman it is difficult because she has to deal with every kind of problem and every kind of emergency when the man is not around to help. For the man it is difficult because he finds himself, when he comes back home a bit purposeless ...' (Ivan)

Ivan aslo describes the dilemma between a husband and his wife, especially at an earlier stage in their relationship:

'Young people they need to be and they want to be next to each other, they want to be together, and it is the right thing, but somebody must do the job ...'

And then he concludes with the hard and true reality that seafarers and their spouses 'must accept the disadvantages of the advantage they all enjoy.' In the end the disadvantages became so much that he and his wife decided to get divorced:

'... but it comes to a point where you don't want your children as they grow further, you know, to witness, since that are not good, positive, not educational at least, for them. So, then rather take a clear cut, you know.' (Ivan)

Another seafarer, a captain from the Philippines called Noel (who had enough English vocabulary to be understandable, 
but did not use the normal sentence structure and whose accent was very hard to follow), described how it becomes at times too long for him to stay at home: '... when I am home two months, I feel restless, only because, the routine just in the house ... children in school ... my wife ... and it's not only me, most seamen ...' Seafarers are not always at home, at home: 'Yah, because you already, feel bored already.' And even Noel's wife feels it becomes too much: 'Because sometimes see my wife said I saw only so much things now so: "You better go!"' For this reason Noel concludes: 'So the life of seaman is quite very hard...' At home his wife says: 'You better go!' But to be at sea is also not always a 'bed of roses', because if you are at sea Noel says: '... you have to fight for it, because if you're lonely you're lost, you want to go home, you lose your job.'

Otto (2002:10) describes how seafarers get caught up in longing for home when they are at sea and longing to be back at sea when they are at home. One of the chaplains described the situation like this:

I believe that a sailor experiences ambivalence. When he is at home he wants to be at sea and when he is at sea he wants to be at home. He never really feels 'at home'. He loses his place there. He becomes an 'outsider' in his own home. (p. 10)

Another chaplain remembers a seafarer saying: 'Sometimes I feel like a spare part and long to return to the vessel.'

Stipp (2011) also picked up on this theme and stated how this becomes a reoccurring pattern in which a family can get stuck:

There is a pattern of circular interaction during the seafarers contact with their families. There is usually a period where they are delighted to be home after a long period and they would describe it as the 'honeymoon phase'. Their families are glad that they are home and everything is seen through a rainbow lens. Slowly life would turn to normal again for the family around school, work and other commitments. The seafarer would see himself as the outsider with not much authority as his wife and children has [sic] learned to cope without him. When he tries to redefine his role as husband and father it is met with resistance from his wife and children. Some of the seafarers would describe this period as one where they got [sic] bored, frustrated or even depressed. Slowly the longing to return to the life at sea would start to grow. The pattern would start again where he returns to sea and have [sic] a longing to be home till he eventually returns.

This seems to be a hopeless situation, but although it is a constant challenge it can be overcome. Stipp (2011) says: 'These circular patterns sometimes change when the family realises that they are stuck and are able to do something different.' An example of this is seen in a letter that the wife of a Filipino seafarer has written (in Otto 2002:14) who was able to interact differently with her husband. Concerning this Stipp (2011) says:

The seafarer's wife broke this pattern when she became a Christian. She involved her husband in praying when he was home. A change in their relationship and family interactions was facilitated and they found a new way to relate to each other that was more positive overall.
Thus, a positive change is possible in spite of all the challenges that seafaring poses to a marriage. This is perhaps an important field of ministry to which those in the seafarers' mission can give attention: to help seafarers in the struggles of their marriage relationships which seem to be set up for failure due to their careers. But it is not only their marriage relationships that are under great pressure, it is also their relationships with their children.

John mentioned that for him, his relationship with his children is easier than his relationship with his wife: 'Yah, my children are more understanding, maybe because they are children. It has not been very easy with my wife.' Even though it is sometimes easier with children, it does not mean that there are not serious struggles. Ivan gave an example of how bad it can be:

'... it is so nice, the mother leaves her in the morning with me to go to work and she starts screaming blue murder, you know: "Mommy, mommy who are you leaving me with?" And yes, slowly, gradually you know, it comes, to the right level of relationship, you know, but, but it is a problem.'

He continued to say that the children will accept the mother's authority, but as far as the father is concerned: 'It's a problem when a father finds, you know, that no one listens to him ...' That is why one of Ivan's colleagues said: 'Here I'm the boss, at home I am nobody.' When I shared this with one of the chaplains she replied: 'Heard that one a few times!'

Eric, a Filipino chief cook who was separated from his wife did not have this experience. For him his daughters, who were teenagers, only wanted him to stay longer and he was missing them very much. After we had been talking about his home he said:

'Actually I do not want to think about all that kind of things, because it makes me feel sad all the time. The things that you miss, you know, things you ... I mean, I spend most of my time here sailing, missing a lot of special occasions ...'

Eric does not only miss many special occasions like Christmas, but he also misses other members of the household: 'Oh, I miss them; you see I have one special dog ...' This is why Stipp (2011) pointed out that in the stories she read there was a feeling of loss as far as the family is concerned:

There is a strong theme of loss characterising each story. It is the loss of the relationship with their families. It is the constant loss of saying goodbye to their loved ones when they have to return to their life at sea. It is also the loss of years without their families that they can never get back.

But Eric keeps his perspective as to why he is doing it:

'Oh, that's life, missing a lot of things, but it's kinda rewarding also because, see, as I told you I was able to send them to $[a]$ good school and provide them all their needs and helping most members of my own family ...'

In order to keep the right perspective many seafarers find strength in their relationship with God. John said: '... God helped me, when I came back I met her and it has been a wonderful marriage with her for this long.' And the seafarer's wife said in her letter: 
The change came when I came into a personal relationship with the Lord Jesus Christ. Slowly I learned to trust in Christ despite the many problems. I learned to tell Jesus all my sorrows and problems, and healing started to take place. Soon after Jesus changed me, my husband also came to know Jesus. When my husband comes home now, we take time in prayer and spend our time together with God's help. (Otto 2002:14)

\section{The Ending}

In this article a conversational construction of an understanding took place. The aim was that it should be a rich or thick description which would open up the possibility of interpretations which could point beyond the local context (cf. Müller 2004:304). These types of descriptions might lead to deconstruction of negative narratives (cf. Müller 2004:304) which find their origin in thin descriptions. The understanding was co-constructed by all the co-researchers including the researcher.

According to Müller et al. (2001:90) narrative research deliberately does not end with a conclusion because the end should be open. Narrative research 'creates its own story with new possibilities' (Müller et al. 2001:89). Therefore, the ending is only the end of a research project or the end of an article with the emphasis that the ending is open and that it must create new possibilities. As was pointed out in the beginning, the end might be disappointing, but the perspective is new and in this sense it is better than the beginning (Müller 2003:15).

This article invites the reader to look at seafarers not in a stereotypical way, but to see them as human beings with complexities and contradictions in their lives like everyone else (cf. Morgan 2000:12). Additionally, this article is directed at those who are involved in the ministry to and with seafarers, and to help them to reflect on the practice of their ministry, based on this socially constructed understanding. In the end(ing), what does this rich understanding consist of and what possible implications can this understanding have as far as the practice of the seafarers' mission are concerned?

The understanding that was constructed indicated that seafarers find their relationship with their families to be very challenging. This is not surprising, but what the research did was to give life to this understanding and to thicken it. Between the husband (generally the seafarer), the wife (generally the one to stay at home), the children and The $J o b$ there are a lot of forces that influence the relationship. It is a constant battle for balance, which at times ends in a divorce or at least in very strained relationships. In John's words there were glimpses of feelings of powerlessness and hopelessness: 'And no matter how I try, that is just the way the job is.' Or even: ' ... that's just the way it is.' On the other hand, this understanding included descriptions and phrases which suggest strength and resilience in the relationship between seafarers and their families. In John's case especially, it was clear how he found strength from the perspective of God's presence in his life. What then are the implications of this understanding for the practice of the ministry? Although the scope of this article was not to construct a detailed model of ministry, it was motivated by pastoral and missionary concerns. For this reason, it points towards a missionary practice where the challenges that seafarers face become opportunities in which a ministry can grow which is relevant and helpful to them.

As Müller et al. (2001:90) pointed out, the ending is open and this open ending invites further research and reflection. The hope is that the ministry will keep on co-constructing alternative events with seafarers from the perspective of the presence of God in Christ (cf. Müller 2005:73). Then more seafarers will be able to witness concerning the ministry like John had when he said:

'... I got into serious discouragement and pain, but often times [I] heard of your organization here, seafarers' [mission], Durban, South Africa. I've always recovered, and when I recover I noticed that the peace of God is still full inside me and that God has not abandoned me and that has kept me to keep moving.'

\section{Acknowledgments Competing interest}

The authors declare that they have no financial or personal relationship(s) which may have inappropriately influenced them in writing this article.

\section{Authors' contributions}

This article has been adapted from the PhD dissertation of C.J.V. (University of Pretoria) which was completed under the supervision of J.C.M. (University of Pretoria).

\section{References}

Bosch, D.J., 1991, Transforming mission: Paradigm shifts in theology of mission, Orbis Books, New York.

Demasure, K. \& Müller, J., 2006, 'Perspectives in Support of the Narrative Turn in Pastoral Care', Nederduitse Gereformeerde Teologiese Tydskrif 47(3/4), 410-419.

Dreyer, J.S., 1998, 'The researcher and the researched: Methodological challenges for practical theology', Praktiese Teologie in Suid Afrika 13(1), 14-27.

Epston, D. \& White, M., 1990, Narrative means to therapeutic ends, W. W. Norton \& Company, Inc., New York.

Geertz, C., 1973, 'Thick description: Toward an interpretive theory of culture', in The interpretation of cultures: selected essays, viewed 10 December 2011, from http://0 people.ucsc.edu.innopac.up.ac/za/ ktellez/geertz1973.pdf

Gergen, K.J., 1985, 'The Social Constructionist Movement in Modern Psychology', American Psychologist 40(3), 266-275. http://dx.doi.org/10.1037/0003066X.40.3.266

Gergen, K.J., 1993, 'Commentary: Belief as relational resource', The International Journal for the psychology of religion 3(4), 321-235. http://dx.doi.org/10.1207/ s15327582ijpr0304_2

Gergen, K.J., 2001, 'Psychological Science in a Postmodern Context', American Psychologist 56(10), 803-813.http://dx.doi.org/10.1037/0003-066X.56.10.803, PMid:11675987

Kverndal, R., 2008, The way of the sea: The changing shape of mission in the seafaring world, William Carey Library, Pasadena.

Mooney, P.G., 2005, Maritime mission: History, developments, a new perspective, Uitgeverij Boekecentrum, Zoetermeer.

Morgan, A., 2000, What is narrative therapy? An easy-to-read introduction, Dulwich Centre Publications, Adelaide.

Müller, J.C., 1996, Om tot verhaal te kom: 'n Pastorale gesinsterapie, RGN Uitgewery, Pretoria.

Müller, J.C., 2001, 'Therapy as fiction writing', Nederduits Gereformeerde Teologiese Tydskrif 42(1/2), 64-70. 
Müller, J.C., 2003, 'Unheard stories of people infected and affected by HIV/AIDS about care and the lack of care: The research story of the project', Practical Theology in SA 18(3), 1-19.

Müller, J.C., 2004, 'HIV/AIDS, narrative practical theology, and postfoundationalism: The emergence of a new story', HTS Teologiese Studies/Theological Studies 60(1/2), 293-306.

Müller, J.C., 2005, 'A postfoundationalist, HIV-positive practical theology', Practical Theology in South Africa 20(2), 72-88.

Müller, J.C., 2009, 'Transversal Rationality as a practical way of doing interdisciplinary work, with HIV and Aids as a case study', Practical Theology in South Africa 24(2), 199-228

Müller, J., 2011, 'Postfoundational practical theology for a time of transition', HTS Teologiese Studies / Theological Studies 67(1), Art. \#837, 5 pages, viewed 23 July
2011 , from http://0-www.hts.org.za.innopac.up.ac.za/index.php/HTS/article/ 2011, from http://0-www.hts.org.za.innopac.up.ac.za/inc
view/837/1573, http://dx.doi.org/10.4102/hts.v67i1.837

Müller, J., Van Deventer, W. \& Human, L., 2001, 'Fiction writing as metaphor fo research: A narrative approach', Practical Theology in South Africa 16(2), 76-96.

Neuman, W.L., 1997, Social research methods: Qualitative and quantitative approaches, Allyn and Bacon, Boston.

Niemandt, N., 2007, Nuwe drome vir nuwe werklikhede, Lux Verbi, Wellington.

Otto, M., 2002, Seafarers! A Strategic Missionary Vision, Piquant, Carlisle.

Ponterotto, J.G., 2006, 'Brief note on the Origins, Evolution, and Meaning of the Qualitative Research Concept "Thick Description", The Qualitative Report 11(3), 538-549.
Stipp, S., 2011, e-mail, 24 May, email address unavailable.

Stone, J.A., 2000, 'J. Wentzel Van Huyssteen: Refiguring rationality in the postmodern age', Zygon 35(2), 415-426. http://dx.doi.org/10.1111/0591-2385.00284

Thayser, E.M., 2001, 'Confronting the legacy of peer persecution: A narrative study', unpublished Master's dissertation, Department of Psychology, Rand Afrikaans University.

Tronche, G., 2008, 'Ministry among fishers: Issues of justice, safety and health', in R. Kverndal (ed.), The way of the sea: The changing shape of mission in the seafaring world, pp. 381-384, William Carey Library, Pasadena.

Trotter, H., 2008, Sugar Girls \& Seamen: A journey into the world of dockside prostitution in South Africa, Jacana Media, Johannesburg.

Van der Westhuizen, Z., 2010, 'Transversality and interdisciplinary discussion in postfoundationalist practical theology - reflecting on Julian Müller's interdisciplinary guidelines', HTS Teologiese Studies/Theological Studies 66(2), Art \#910, 5pages. http://dx.doi.org/104102/hts.v66i2.910

Van Huyssteen, J.W., 1997, Essays in Postfoudationalist Theology, Eerdmans Publishing Co., Michigan.

Van Huyssteen, J.W., 2000, 'Postfoundationalism and Interdisciplinarity: A response to Jerome Stone', Zygon 35(2), 427-439. http://dx.doi.org/10.1111/05912385.00285

Wildman, W.J., 2008, 'Hand in glove: Evaluating the fit between method and theology in Van Huyssteen's interpretation of human uniqueness', Zygon 43(2), 475-491. http://dx.doi.org/10.1111/j.1467-9744.2008.00929.x 